\title{
Sulfur Speciation in the Surface Sediments of Lakes from Different Regions, China: Characterization by $S$ K-Edge XANES Spectroscopy
}

\author{
Wang Jingfu, ${ }^{1}$ Chen Jingan, ${ }^{1}$ Dai Zhihui, ${ }^{2}$ Yang Haiquan, ${ }^{1}$ and Ma Chenyan ${ }^{3}$ \\ ${ }^{1}$ State Key Laboratory of Environmental Geochemistry, Institute of Geochemistry, Chinese Academy of Sciences, Guiyang 550081, China \\ ${ }^{2}$ State Key Laboratory of Ore Deposit Geochemistry, Institute of Geochemistry, Chinese Academy of Sciences, Guiyang 550081, China \\ ${ }^{3}$ Institute of High Energy Physics, Chinese Academy of Science, Beijing Synchrotron Radiation Facility, Beijing 100049, China \\ Correspondence should be addressed to Chen Jingan; chenjingan@vip.skleg.cn
}

Received 9 March 2016; Accepted 28 April 2016

Academic Editor: Stanislav Frančišković-Bilinski

Copyright (C) 2016 Wang Jingfu et al. This is an open access article distributed under the Creative Commons Attribution License, which permits unrestricted use, distribution, and reproduction in any medium, provided the original work is properly cited.

\begin{abstract}
$\mathrm{X}$-ray absorption near edge structure (XANES) spectroscopy affords the opportunity to determine redox status for element $\mathrm{S}$ in the aquatic ecosystems. However, there have been relatively few studies of S XANES spectroscopy in the terrestrial aquatic ecosystems. In this study, XANES technology was used to examine changes in S speciation in the sediments collected from Taihu Lake, Qinghai Lake, Dianchi Lake, Caohai Lake, and Hongfeng Lake located in distinct geological background areas of China. The results showed that sedimentary S in Qinghai Lake has a high proportion of sulfate averaged 88.9\% due to physical weathering of watershed rocks, while deposited S in Taihu Lake has a high fraction of intermediate S (36.5\%), which may be the response of the agricultural nonpoint source pollution in drainage basin. The three lakes located in Southwest China have similar composition characteristics of S species, indicating similar S sources including chemical weathering of carbonate and atmospheric deposition. 60-90\% of S compounds in the surface sediments were in the form of sulfate and FeS. In deeper layers, the ratio of FeS $\mathrm{F}_{2}$ and the intermediate $\mathrm{S}$ significantly increased, suggesting rapid processes of sulfate reduction and sulfide reoxidation with the increasing depths.
\end{abstract}

\section{Introduction}

Sediment is an important repository and sink for sulfur (S) [1]. The biogeochemical cycles of $S$ in sediments were highly complex, because the aquatic ecosystems have anaerobic zones which strongly affect the chemical forms of $S[2,3]$. In the previous studies, the wet-chemical speciation method was generally used to analyze the $S$ speciation in sediments and reveal its geochemical processes in the aquatic ecosystems [49]. In fact and often neglected, $S$ in natural samples existed in a large variety of organic and inorganic forms with different electronic oxidation states, ranging from -2 (inorganic sulfide) to +6 (sulfate) [10]. This made traditional wet-chemical $\mathrm{S}$ speciation complicated [11]. Therefore, sensitive analytical methods are needed to analyze and monitor many functions and transformations of $S$ species in biochemical reactions and in our environment [12]. X-ray absorption near edge structure (XANES) spectroscopy affords the opportunity to determine redox status and coordination environment for a wide variety of elements, including sulfur, carbon, and nitrogen within these sediments [13]. The method has become especially attractive for the speciation of $S$ in sediments and other environmental samples, most prominently at the $\mathrm{S} \mathrm{K}$ edge $[10,12,14,15]$.

In previous investigations, XANES spectroscopy has been applied to the analysis of the chemical form and oxidation state of $S$ in soil and marine sediments $[10,12,16]$, providing information about the deposition and diagenesis of organic matter and S mineralogy. However, there have been relatively few studies of S XANES spectroscopy in sediments of the terrestrial aquatic ecosystems [17]. Particularly, comparative studies of the oxidation states of sedimentary $S$ in different types of lakes from distinct geological background areas are scarce. In this study, we used the K-edge XANES to determine $S$ speciation in the sediments collected from Taihu Lake (Eastern China), Qinghai Lake (Western China), 


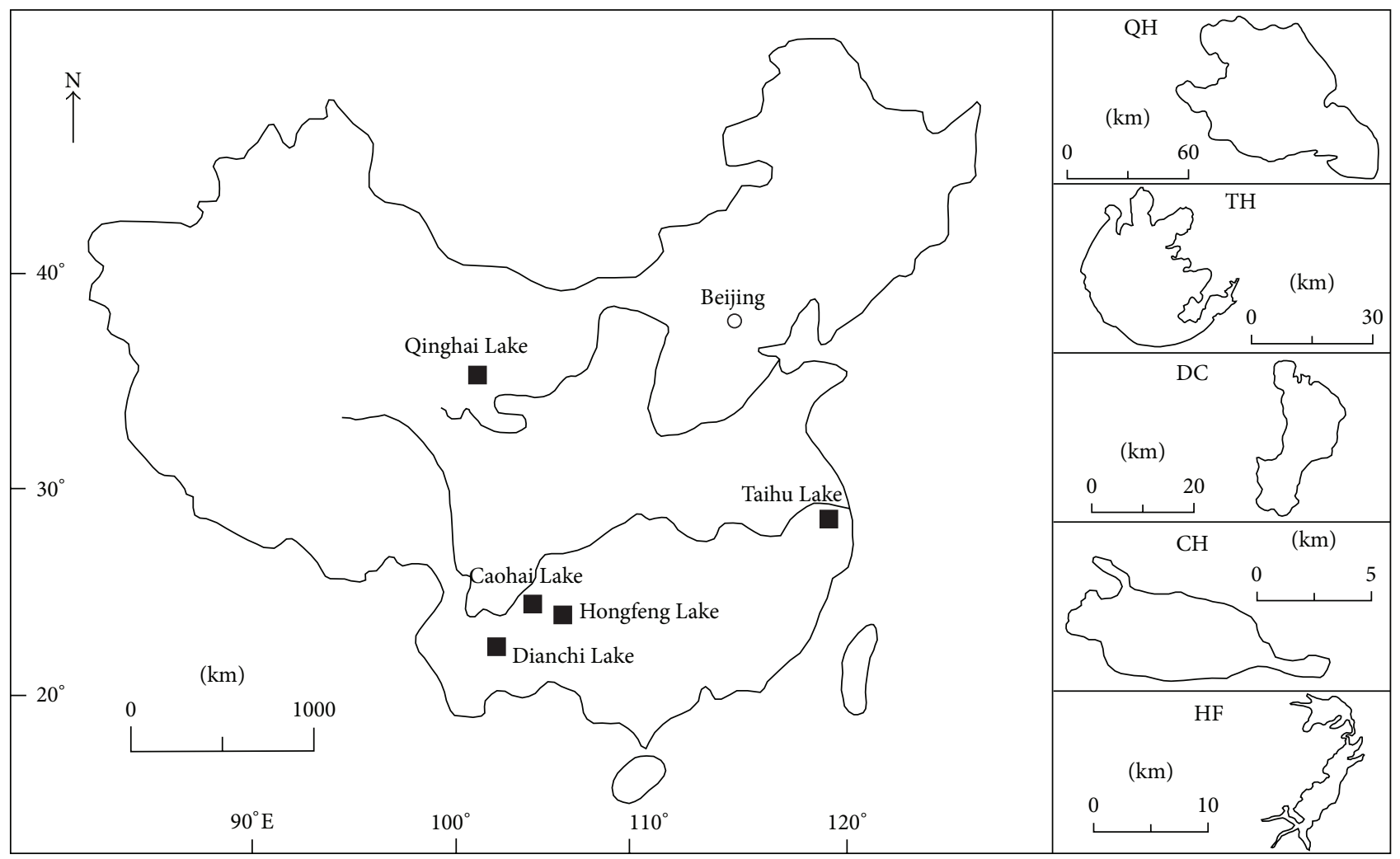

FIgURE 1: Location of the studied lakes.

Hongfeng Lake (Southwest China), Caohai Lake (Southwest China), and Dianchi Lake (Southwest China). The object is to understand the $S$ speciation and its transformation in sediments of the terrestrial aquatic ecosystems.

\section{Materials and Methods}

2.1. Area Description. In this study, five lakes were chosen based on economic and geographic status in the Yangtze River region, Southwest Plateau, and Qinghai-Tibet Plateau, China (Figure 1). Geographic and limnological features for the five selected lakes are shown in Table $1[18,22]$. Taihu Lake is the third largest freshwater lake in China located at the downstream of the Changjiang River. More than 200 brooks, canals, and rivers discharge industrial wastewater, mostly from nearby cities, into the lake. Many effluents contain pesticides, toxic chemicals, or heavy metals. Southwest Plateau China is the largest karst area in China. According to previous lake chemistry surveys [23], one slightly polluted lake (Caohai Lake) and two heavily polluted lakes (Dianchi and Hongfeng Lakes) were selected in this area. Qinghai Lake, a closed-basin lake, is the largest inland saline lake in China. The amount of evaporation ( $\sim 1400 \mathrm{~mm} /$ year $)$ is in excess of the mean annual precipitation $(\sim 400 \mathrm{~mm} /$ year $)$, resulting in the development of a saline lake.

2.2. Sampling Procedures. Sediment core samples were obtained from the five lakes in September 2013, nearly in the centre of the lakes. A plastic static gravity corer with
$30 \mathrm{~cm}$ length and $6 \mathrm{~cm}$ diameter Plexiglas cylinder tube was employed to obtain the sediment cores. The core samples were sliced with intervals of $2 \mathrm{~cm}$, with the exception of the core from Qinghai Lake sectioned at $1 \mathrm{~cm}$ intervals. Sediments were handled under protective nitrogen atmospheres (purity 99.9\%, Guiyang Shenjian Gas Co., Ltd.). All samples were put in sealed plastic bag and immediately transferred to laboratory in iceboxes $\left(<4^{\circ} \mathrm{C}\right)$ and freeze-dried. After that, the samples were frozen with liquid nitrogen. Before XANES analysis, dry samples were ground and sieved with a standard 100-mesh sieve.

2.3. Sulfur K-Edge XANES. The sulfur K-edge XANES spectra were recorded at $4 \mathrm{~B} 7 \mathrm{~A}$ beamline (medium X-ray beamline 2100-6000 eV) using synchrotron radiation from Beijing Synchrotron Radiation Facility, the Institute of High Energy Physics, the Chinese Academy of Sciences. The samples were pressed into thin films before analysis. The storage ring was operated at the energy of $2.5 \mathrm{GeV}$ with $\mathrm{Si}$ (111) double crystals. Spectra were scanned at step widths of $0.3 \mathrm{eV}$ in the region between 2420 and $2520 \mathrm{eV}$, with fluorescence mode using a fluorescent ion chamber Si (Li) detector (PGT LS30135). Additional filters were placed between the sample and the detector to reduce the fluorescence signal derived from $\mathrm{Si}$ in the samples.

Fe monosulfide (FeS), pyrite $\left(\mathrm{FeS}_{2}\right), \mathrm{R}-\mathrm{SH}, \mathrm{RSOR}^{\prime}$, $\mathrm{Na}_{2} \mathrm{SO}_{3}, \mathrm{NaRSO}_{3}$, and $\mathrm{Na}_{2} \mathrm{SO}_{4}$ were chosen as the standard compounds. Electronic oxidation states, white-line energies, and intensities of reference $S$ compounds were shown in 
TABLE 1: Geographic and limnological features of the studied lakes [18-21].

\begin{tabular}{|c|c|c|c|c|c|}
\hline \multirow{2}{*}{ Parameters } & \multirow{2}{*}{$\begin{array}{l}\text { Eastern China } \\
\text { Taihu Lake }\end{array}$} & \multicolumn{2}{|c|}{ Southwestern China } & \multirow[b]{2}{*}{ Caohai Lake } & \multirow{2}{*}{$\begin{array}{c}\text { Western China } \\
\text { Qinghai Lake }\end{array}$} \\
\hline & & Hongfeng Lake & Dianchi Lake & & \\
\hline Positions & $\begin{array}{l}30^{\circ} 05^{\prime}-32^{\circ} 08^{\prime} \mathrm{N} \\
119^{\circ} 08^{\prime}-121^{\circ} 55^{\prime} \mathrm{E}\end{array}$ & $\begin{array}{l}26^{\circ} 25^{\prime}-34^{\prime} \mathrm{N} \\
106^{\circ} 20^{\prime}-28^{\prime} \mathrm{E}\end{array}$ & $\begin{array}{c}24^{\circ} 40^{\prime}-25^{\circ} 02^{\prime} \mathrm{N} \\
102^{\circ} 36^{\prime}-{ }^{\circ} 47^{\prime} \mathrm{E}\end{array}$ & $\begin{array}{l}26^{\circ} 49^{\prime}-53^{\prime} \mathrm{N} \\
104^{\circ} 12^{\prime}-18^{\prime} \mathrm{E}\end{array}$ & $\begin{array}{l}36^{\circ} 32^{\prime}-37^{\circ} 15^{\prime} \mathrm{N}, \\
99^{\circ} 36^{\prime}-100^{\circ} 47^{\prime} \mathrm{E}\end{array}$ \\
\hline Surface area $\left(\mathrm{km}^{2}\right)$ & 2338 & 56 & 306 & 20 & 4583 \\
\hline Elevation $(\mathrm{m})$ & 5 & 1235 & 1886 & 2171 & 3196 \\
\hline Maximum depth (m) & 2.6 & 45.0 & 8.0 & 2.5 & 32.8 \\
\hline \multicolumn{6}{|l|}{ Water } \\
\hline $\mathrm{pH}$ & 8.36 & 8.40 & 7.37 & 8.78 & 9.35 \\
\hline $\mathrm{DO}(\mathrm{mg} / \mathrm{L})$ & 10.1 & 8.8 & 8.9 & 9.4 & ND \\
\hline Salinity (g/L) & $<1.0$ & $<1.0$ & $<1.0$ & $<1.0$ & 12.5 \\
\hline Sulfate (mg/L) & 100 & 80 & 60 & 40 & 2500 \\
\hline \multicolumn{6}{|l|}{ Sediment } \\
\hline Organic matter (\%) & 6.5 & 5.4 & 6.5 & ND & 2.4 \\
\hline $\mathrm{TN}(\%)$ & ND & 0.31 & 0.33 & 1.38 & 0.50 \\
\hline $\mathrm{TP}(\%)$ & 0.08 & 0.16 & 0.15 & 0.07 & ND \\
\hline $\mathrm{Fe}(\%)$ & 2.65 & 5.98 & ND & ND & 2.50 \\
\hline Climate type & Warm, humid & $\begin{array}{c}\text { Warm, } \\
\text { semihumid }\end{array}$ & $\begin{array}{c}\text { Warm, } \\
\text { semihumid }\end{array}$ & $\begin{array}{c}\text { Warm, } \\
\text { semihumid }\end{array}$ & Cool, semiarid \\
\hline Deposition rate $(\mathrm{cm} / \mathrm{yr})$ & ND & 0.16 & 0.20 & 0.25 & 0.10 \\
\hline
\end{tabular}

Table 2. The X-ray energy was calibrated with reference to the spectrum of the highest resonance energy peak of $\mathrm{Na}_{2} \mathrm{SO}_{4}$ at $2480.4 \mathrm{eV}$. For all edge-normalized spectra, the contribution of different $S$ species to total $S$ was calculated using the software package ATHENA (Ravel and Newville, 2005). Linear combination fitting (LCF) was carried out in the energy range 2466-2487 eV using the ATHENA [10].

2.4. Analysis of the Total Sulfur. Total S contents were measured with an elemental analyzer (vario MACRO cube, Elementar, Germany), with an experimental error of $0.5 \%$. Two certified reference materials (RTS-2 and KZK-1, State Key Laboratory of Environmental Geochemistry, Institute of Geochemistry, CAS) were used as calibration standard. Concentrations of total $\mathrm{S}$ in sediments of the five studied lakes were shown in Table 3.

\section{Results and Discussion}

3.1. S Species in Lake Sediments. Our sediment samples each contain both oxidized and reduced sulfur species as shown in Figure 2. Two major absorption bands were observed in these K-edge XANE spectra: one near $2472 \mathrm{eV}$ region for the reduced $\mathrm{S}$ compounds (e.g., $\mathrm{FeS}$ and $\mathrm{FeS}_{2}$ ) and another near $2483 \mathrm{eV}$ region for oxidized $\mathrm{S}$ species (e.g., $\mathrm{SO}_{4}{ }^{2-}$ ), suggesting that sulfate and FeS were the most important component of elemental S in all lakes. However, in different lakes, the compositions of the oxidation state of $\mathrm{S}$ in sediments were still very different. Figure 2 showed that the overall absorption intensity of $\mathrm{S}$ was the lowest in the sediment of Taihu Lake, indicating the lowest concentration of S component in the sediments. Further, organic state $S$ obviously occupied a
TABLE 2: Electronic oxidation states, white-line energies, and intensities of reference $\mathrm{S}$ compounds.

\begin{tabular}{lccc}
\hline Compound & $\begin{array}{c}\text { Electronic } \\
\text { oxidation state }\end{array}$ & $\begin{array}{c}\text { White-line } \\
\text { energy (eV) }\end{array}$ & $\begin{array}{c}\text { White-line } \\
\text { intensity }\end{array}$ \\
\hline $\mathrm{FeS}$ & -2 & 2472.2 & 1.17 \\
$\mathrm{FeS}_{2}$ & -1 & 2472.8 & 1.33 \\
$\mathrm{RSH}$ & +0.5 & 2473.4 & 1.58 \\
$\mathrm{RSOR}^{\prime}$ & +2 & 2476.2 & 1.81 \\
$\mathrm{Na}_{2} \mathrm{SO}_{3}$ & +3.68 & 2478.4 & 2.03 \\
$\mathrm{NaRSO}_{3}$ & +5 & 2481.2 & 2.33 \\
$\mathrm{Na}_{2} \mathrm{SO}_{4}$ & +6 & 2482.6 & 2.54 \\
\hline
\end{tabular}

relatively high proportion of in the oxidation state of $S$ in sediments of Taihu Lake, compared with other lakes. In the three lakes located in the Southwestern China, that is, Dianchi Lake, Caohai Lake, and Hongfeng Lake, the oxidation state of the sedimentary $\mathrm{S}$ presented similar composition characteristics. The concentrations of sulfate, $\mathrm{FeS}$, and $\mathrm{S}_{2} \mathrm{O}_{3}{ }^{2-}$ were high of the top three, and the contents of other $\mathrm{S}$ forms were relatively low. In the sediments of Qinghai Lake, the oxidation states of S were mainly sulfate, $\mathrm{FeS}$, and $\mathrm{FeS}_{2}$ and almost no organic sulfur. Moreover, $\mathrm{FeS}_{2}$ was found in the surface sediments of Taihu Lake and Qinghai Lake and did not exist in the surface sediments of the three lakes located in Southwestern China.

Figure 2 also demonstrated that the absorption intensity of $\mathrm{S}$ significantly reduced with the increasing depths in all sediment profiles, revealing a reduction of the concentration of $\mathrm{S}$ in deeper layers. Figure 3 showed the vertical variation of the oxidation states of $S$ in the sediment profiles, suggesting 
TABLE 3: Concentrations of total S in sediments of Taihu Lake, Hongfeng Lake, Dianchi Lake, Caohai Lake, and Qinghai Lake.

\begin{tabular}{|c|c|c|c|c|c|}
\hline Depth cm & Taihu Lake & Hongfeng Lake & Dianchi Lake & Caohai Lake & Qinghai Lake \\
\hline $0-2$ & 0.170 & 0.695 & 0.662 & 1.227 & 0.393 \\
\hline $3-4$ & 0.066 & 0.657 & 0.509 & 1.428 & 0.375 \\
\hline $5-6$ & ND & 0.795 & 0.622 & 1.659 & 0.384 \\
\hline $7-8$ & ND & 0.810 & 0.469 & 1.495 & 0.523 \\
\hline $9-10$ & ND & 1.175 & 0.911 & 1.221 & 0.417 \\
\hline $11-12$ & ND & 0.926 & 0.817 & 0.850 & ND \\
\hline $13-14$ & ND & 0.618 & 0.483 & 1.168 & ND \\
\hline $15-16$ & ND & ND & 0.527 & 0.388 & ND \\
\hline $17-18$ & ND & ND & 0.425 & 0.559 & ND \\
\hline $19-20$ & ND & ND & 0.326 & 0.512 & ND \\
\hline $21-22$ & ND & ND & 0.381 & 0.346 & ND \\
\hline $23-24$ & $\mathrm{ND}$ & ND & 0.136 & 0.425 & ND \\
\hline
\end{tabular}

that $\mathrm{S}$ in sediments changed from the oxidation state to the reduced state with the increasing depths. Oxidation states of $\mathrm{S}$ in Dianchi Lake showed that sulfate and FeS were major forms in the top $10 \mathrm{~cm}$ sediment, which were considered to be the most stable in all oxidation states of $\mathrm{S}$ in sediments. In the deeper layers, the ratio of $\mathrm{FeS}_{2}$ and organic $\mathrm{S}$ forms in the total $S$ was significantly increased, suggesting that sulfate was chemically or biologically reduced in the deep part of the sediments. S in sediments of Caohai and Hongfeng Lake showed similar composition and change characteristics with that in Dianchi Lake. In Qinghai Lake, the proportion of the $\mathrm{FeS}$ and $\mathrm{FeS}_{2}$ slightly increased in $0-6 \mathrm{~cm}$ sediment layer then reduced in the depths of $6-10 \mathrm{~cm}$. Accordingly, the proportion of sulfate reduced first and then increased, suggesting an occurrence of $\mathrm{S}$ reduction and reoxidation processes.

In the large-scale, the five lakes in this study were located in three different natural regions, which have the varied climatic, economic, and geological features. Qinghai Lake basin was an arid climate area in the Northwestern China, where it usually received low inputs of mean annual precipitation and had high potential evapotranspiration [24]. Acid deposition was mainly formed from $\mathrm{SO}_{2}$ emitted to the atmosphere, largely because of fossil-fuel combustion [25]. Qinghai Lake area was essentially unaffected by acid deposition, indicating that atmospheric S has a relatively low concentration [26]. Thus $S$ in sediments of this lake mainly derived from physical weathering of watershed rocks. Taihu Lake was located in the economically developed eastern coastal areas of China. As shown in Figure 3, largely organic S, originated from industry and agriculture in the lake basin, occupied a high proportion in total $\mathrm{S}$ in the sediments. $\mathrm{S}$ in sediments of Taihu Lake, on the one hand, reflected the composition of the soil S of the lake basin and, on the other hand, was affected by human activities such as industry, agriculture, and atmospheric deposition. For the three lakes located in the largest karst region in Southwestern China, that is, Dianchi Lake, Caohai Lake, and Hongfeng Lake, chemical weathering of carbonate was the most important source of $\mathrm{S}$. The previous studies demonstrated that considerable emissions of S compounds mainly occurred in southern and Southwestern
China due to subsequent consumption of coal and oil, which increased rapidly since the 1970s [26]. Dry and wet deposition of atmospheric $S$ caused by the coal combustion may be another important source for these three lakes.

Furthermore, the eutrophic status of lakes may impact on the $\mathrm{S}$ deposition in the lake environment. In our study, most of the lakes have changed from oligotrophy to of mesoor eutrophic conditions during the past decades because of nutrient loading from wastewater and fertilizers, especially Taihu Lake and Dianchi Lake [19, 20]. Only Qinghai Lake was still in the oligotrophy condition. Holmer and Storkholm [27] indicated that deposition of S was generally higher in eutrophic than in oligotrophic lakes because of a number of factors: a higher rate of sulfate reduction, enhanced sedimentation of organic $S$, and less reoxidation as a result of reduced penetration of oxygen into the sediments, a lack of faunal activity, and rooted macrophytes. Our survey data as shown in Figure 3 showed that the proportion of $\mathrm{S}^{2-}$ and $\mathrm{S}_{2}{ }^{2-}$ in the sedimentary $\mathrm{S}$ in the eutrophic lakes, such as Taihu Lake, was indeed significantly higher than that in Qinghai Lake, which was consistent with the results of previous studies [27]. Currently, there is, however, still a general lack of understanding of the interactions between $S$ cycling and eutrophication. One example is the interaction between $S$ cycling and benthic fauna and rooted macrophytes, as they may be significantly impacted by eutrophication [27]. However, we believed that the impacts of $S$ bacteria were more reasonable. $S$ reduced from varied oxidation states into sulfides through the complex biochemical processes was generally assumed to be the dominant pathway for the permanent removal of $S$ in the sediment [5]. Reduction of $S$ in sediments is mainly dominated by SRB, while the eutrophic lakes generally have a high SRB in sediment layers; thus the proportion of most reduced $S$ (oxidation state $<0$ ) in the sediment of eutrophic lake is higher than in oligotrophic lakes. In particular, Hongfeng Lake was a seasonally stratified deep-water lake. After destratification and during winter, the anoxic hypolimnion becomes mixed with overlying oxic water, which enhances oxygen penetration into the sediments. This leads to an increased oxidation of reduced $\mathrm{S}$, followed by a higher sulfate concentration [28]. 

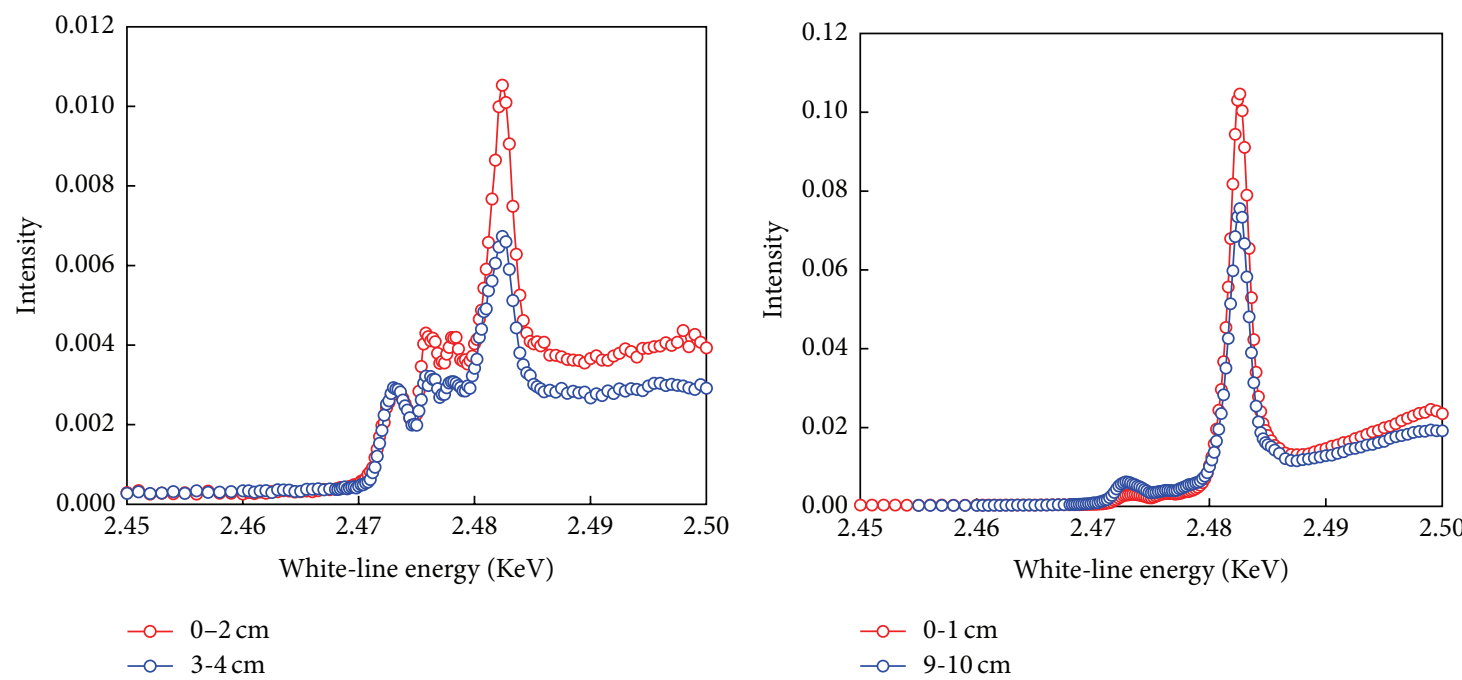

(a) Taihu Lake

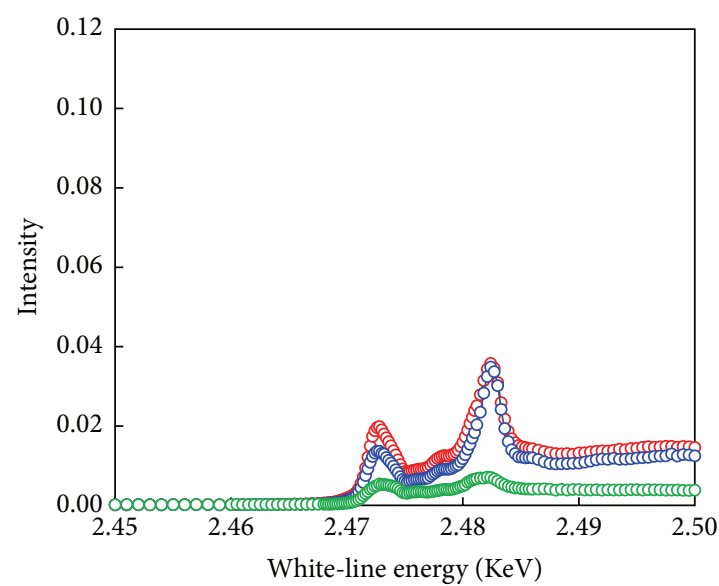

(b) Qinghai Lake

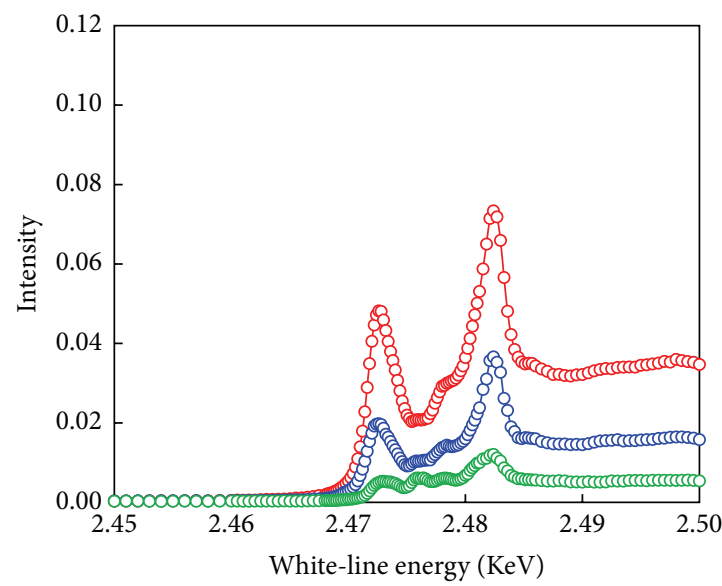
$-0-0-2 \mathrm{~cm}$
$-0-0-2 \mathrm{~cm}$
$-0-9-10 \mathrm{~cm}$
$-0-21-22 \mathrm{~cm}$

(c) Dianchi Lake

(d) Caohai Lake

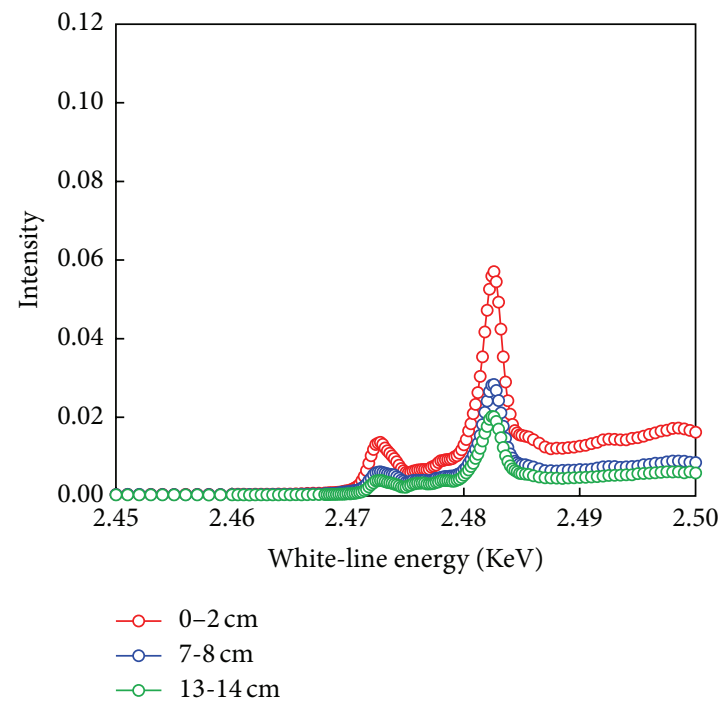

(e) Hongfeng Lake

Figure 2: Vertical variations of oxidation states of different S compounds in sediment profiles of Taihu Lake, Qinghai Lake, Dianchi Lake, Caohai Lake, and Hongfeng Lake, China. 

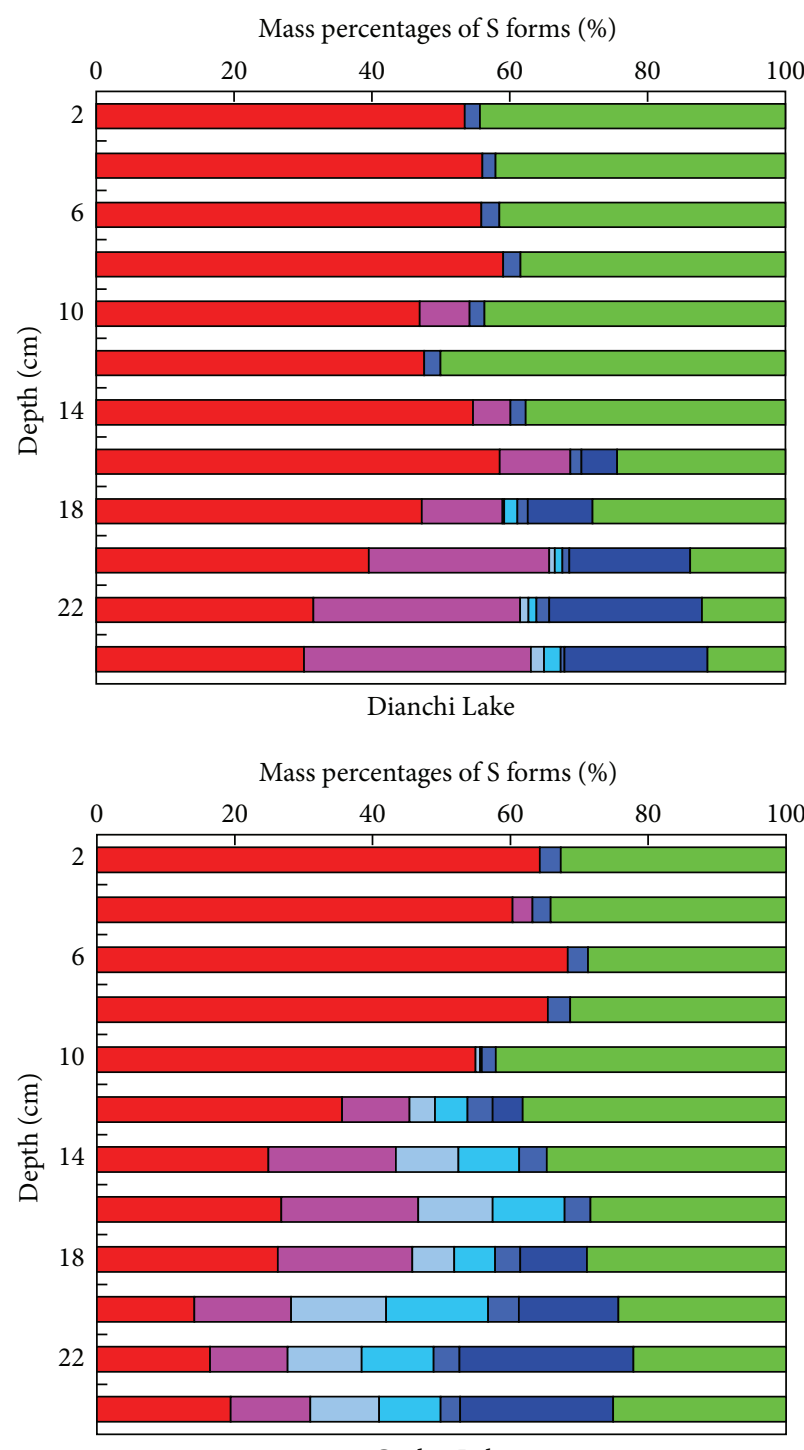

Caohai Lake

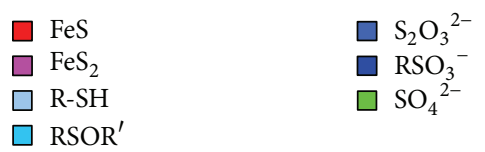

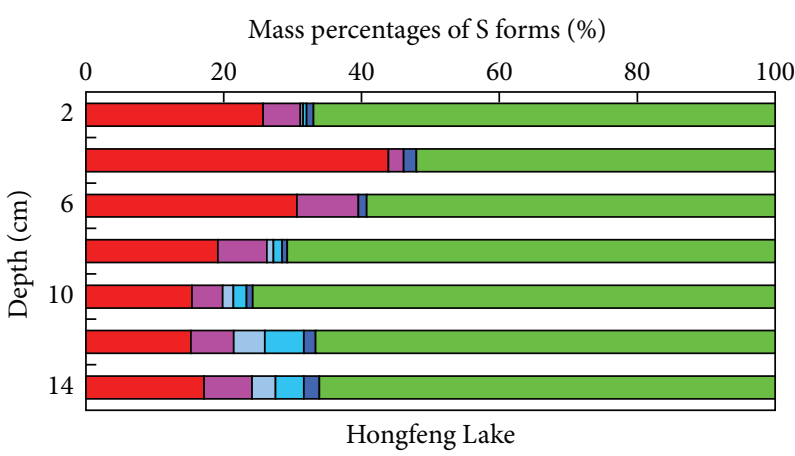
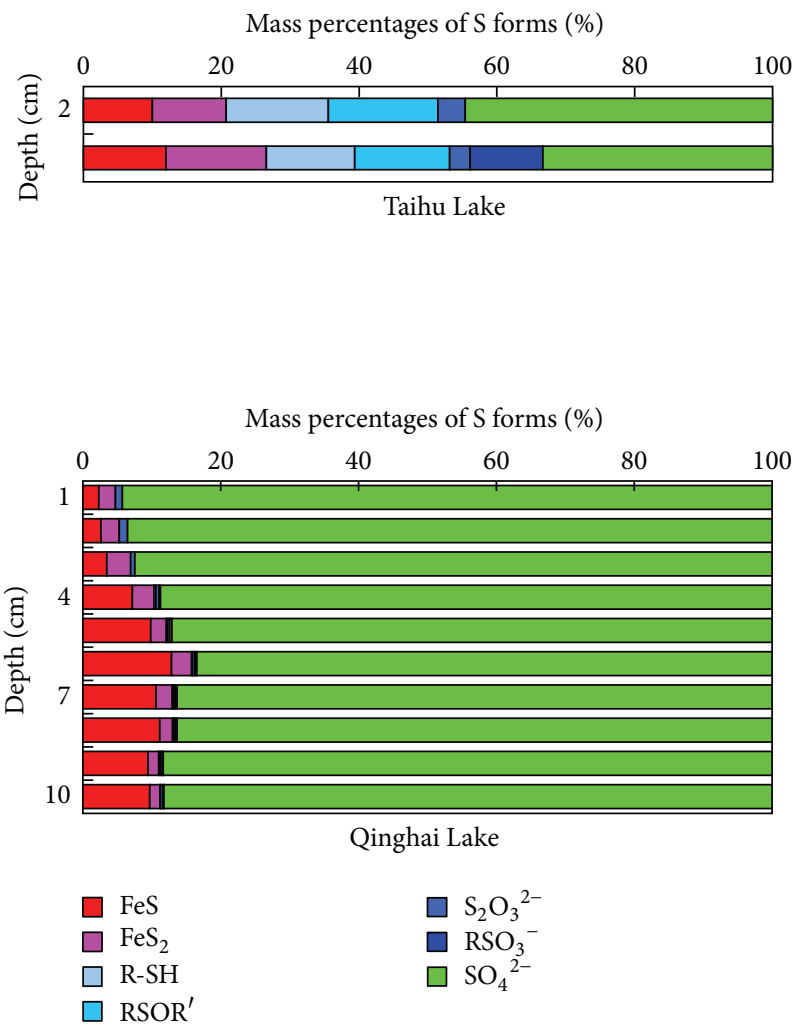

FIgURE 3: Mass percentages of sulfur in FeS, $\mathrm{FeS}_{2}, \mathrm{R}-\mathrm{SH}, \mathrm{RSOR}^{\prime}, \mathrm{SO}_{3}{ }^{2-}, \mathrm{RSO}_{3}{ }^{-}$, and $\mathrm{SO}_{4}{ }^{2-}$ as calculated by Linear Combination Fitting on $\mathrm{S}$ K-Edge XANES spectra.

3.2. Composition Ratio of Different S Compounds in Sediment Profiles. The composition ratios of different $\mathrm{S}$ species in sediment cores were shown in Figure 3. XANES fitting procedures revealed that $60-90 \%$ of the total S compounds near the surface $(0-10 \mathrm{~cm}$ depth) of the lake sediment samples were in the form of sulfate and $\mathrm{FeS}$. FeS 2 and the $\mathrm{S}$ species with intermediate oxidation states between 0 and +6 accounted for a high proportion of total $\mathrm{S}$ in the deeper layers.

Figure 3 showed that there were wide variations in the fractions of the sedimentary $S$ species in different lakes. In the surface sediment of Taihu Lake, sulfate, $\mathrm{FeS}_{2}$, and $\mathrm{FeS}$ accounted for $38.9 \%, 12.6 \%$, and $11.0 \%$ of the total S, while the $\mathrm{S}$ species with intermediate oxidation states between 0 and +6 accounted for $36.5 \%$. In Dianchi Lake, the composition ratio of FeS declined from $53.5 \%$ in surface to $30.2 \%$ in bottom with the increasing depths in the sediments, and the fraction of sulfate declined from $44.3 \%$ to $11.3 \%$. $\mathrm{FeS}_{2}$ was found below the $10 \mathrm{~cm}$ depth, and its relative proportion rapidly increased from $5.4 \%$ to $30.2 \%$ in the deep layers. The fraction of $\mathrm{S}$ species with intermediate oxidation states between 0 and +6 ranged from $2.3 \%$ to $25.6 \%$ in the $10-24 \mathrm{~cm}$ sediments. The composition of sedimentary S species in Caohai Lake and Hongfeng Lake was similar to that in Dianchi Lake.

In particular, sediments from Qinghai Lake contained a very high proportion of sulfate, with an average value of $88.9 \%$. The proportion of the sulfate slightly decreased from 


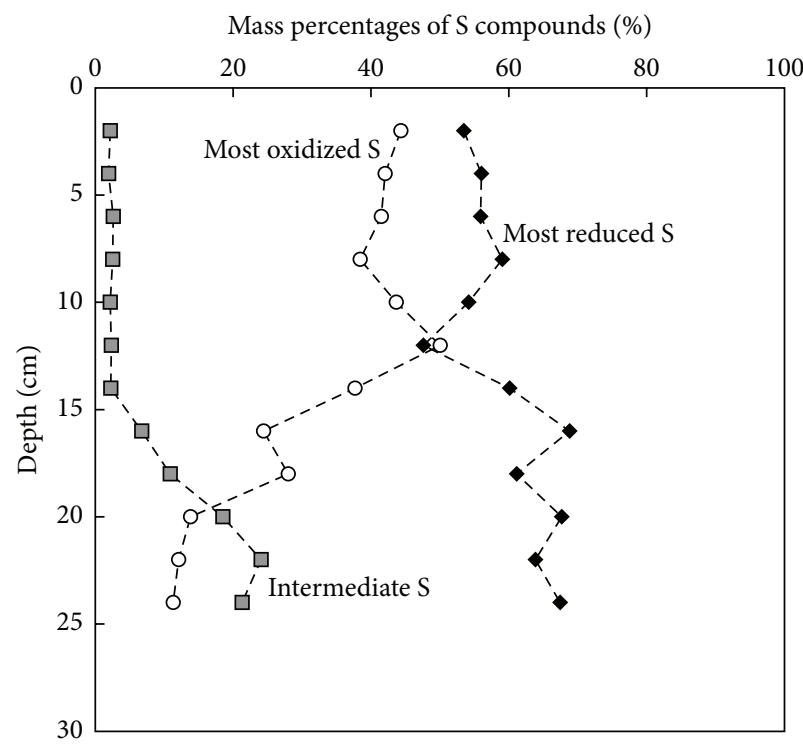

(a)

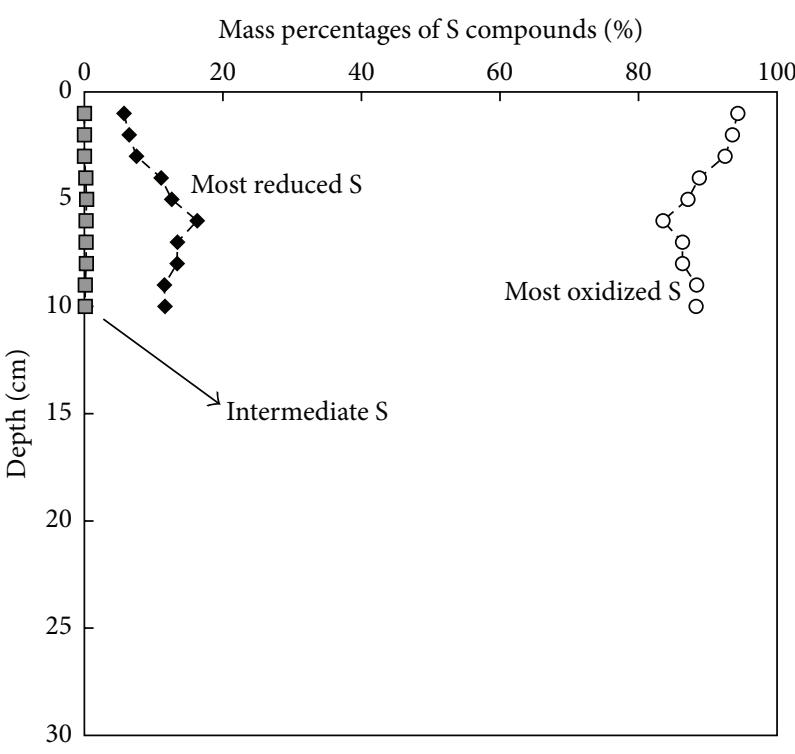

(b)

FIgURE 4: Mass percentages of most reduced S (oxidation state $<0$ ), intermediated $S$ (oxidation state from 0 to +5 ), and most oxidized $S$ (oxidation state +6 ) in the sediments from (a) Dianchi Lake and (b) Qinghai Lake.

$94.3 \%$ to $83.5 \%$ in the depths that ranged from 0 to $6 \mathrm{~cm}$ then slightly increased from $83.5 \%$ to $88.3 \%$ in the $6-10 \mathrm{~cm}$ sediments. The contribution of $\mathrm{FeS}$ and $\mathrm{FeS}_{2}$ was very low, while the $\mathrm{FeS}+\mathrm{FeS}_{2}$ content varied between 4.7 and $15.6 \%$ in all samples. There was no indication of other sulfur species with intermediate oxidation states between 0 and +6 in the core profile of Qinghai Lake.

The combination of S speciation helps to constrain the depositional environment present in these sediments. Similar percentages of most reduced $S$ (oxidation state $<0$ ), intermediated $S$ (oxidation state from 0 to +5 ), and most oxidized S (oxidation state +6 ) in the sediments of Dianchi Lake and Qinghai Lake were calculated by LCF (Figure 4). Our results indicated that the ratio of most oxidized $\mathrm{S}$ reduced in the surface $(0-8 \mathrm{~cm})$ sediment of Dianchi Lake; correspondingly, the proportion of most reduced $\mathrm{S}$ increased, implying the transformation from sulfate to sulfide iron through a strong activity of SRB in the top layer. Sulfate reduction was usually not limited by the sulfate in surface layers, as the concentration exceeds $K_{m}$ for SRB [29]. But limitation may occur deeper in the sediment, because sulfate usually penetrates only to $<10 \mathrm{~cm}$ into freshwater sediments due to its low concentration [27]. As shown in Figure 4(a), at a depth of 8-12 cm layer, the proportion of most reduced $S$ rapidly declined; correspondingly, the proportion of most oxidized S increased, revealing a limitation of sulfate reduction and an occurrence of reoxidation of reduced $S$ in the anaerobic condition. Similar phenomenon was also found in the sediment profile of Qinghai Lake (Figure 4(b)). In the deeper $(>12 \mathrm{~cm})$ layers, intermediated $\mathrm{S}$ gradually occupied a high ratio in the total sedimentary $S$, indicating that the SRB was significantly reduced in those layers, because if any, the bacteria mediated disproportionation reaction will lead to the transition from the unstable intermediate $S$ to the more stable reduced S and sulfate. The intermediated S in deep sediments found in our study was likely to be the major product of sulfide reoxidation in the absence of microorganisms and iron ions.

It should be noted that the intermediate $S$ was stable below $15 \mathrm{~cm}$ depth in sediments from Dianchi Lake, as shown in Figure 4(a). Experiments with ${ }^{35} \mathrm{~S}$ labeled $\mathrm{S}_{2} \mathrm{O}_{3}{ }^{2-}$ demonstrated that $\mathrm{S}_{2} \mathrm{O}_{3}{ }^{2-}$ was disproportionated throughout all redox zones in the upper $10 \mathrm{~cm}$, where disproportionating bacteria were abundant in the sediments [30]. The intermediate $S$ was not commonly found in surface layer sediments because it reacted fast with $\mathrm{Fe}^{3+}$ and was further oxidized to sulfate. Although $\mathrm{Fe}^{3+}$ oxidizes pyrite rapidly in the sediment surface, iron-oxidizing bacteria can increase the oxidation rate by several orders of magnitude [31], supplying $\mathrm{Fe}^{3+}$ for pyrite oxidation. Then in the deep layers where $\mathrm{Fe}^{3+}$ was not available, the intermediate $S$ might be the major end product of pyrite reoxidation [6]. Due to the absence of microorganisms and iron ions, the intermediate $\mathrm{S}$ can keep stable in deep sediments, which was consistent with the results observed in our studies lakes.

\section{Conclusion}

The vertical distributions of sulfur speciation in sediment cores collected from five lakes of China were investigated using XANES spectroscopy. The results showed that $S$ in the sediment of Qinghai Lake (saline lake) had a high proportion of sulfate averaged $88.9 \%$ due to physical weathering of watershed rocks, while $S$ in the sediment of Taihu Lake (freshwater lake) had a high fraction of intermediate S (36.5\%) which may be the response of the agricultural nonpoint source pollution in drainage basin. The three freshwater lakes located in Southwestern China had similar composition characteristics 
of S species, indicating similar sources including chemical weathering of carbonate and atmospheric deposition. In this study, $60-90 \%$ of $S$ compounds near the surface $(0-10 \mathrm{~cm}$ depth) sediment were in the form of sulfate and FeS. In deeper layers, the ratio of $\mathrm{FeS}_{2}$ and the intermediate $\mathrm{S}$, such as R-SH, $\mathrm{RSOR}^{\prime}, \mathrm{S}_{2} \mathrm{O}_{3}{ }^{2-}$, and $\mathrm{RSO}_{3}{ }^{-}$, significantly increased, suggesting rapid processes of sulfate reduction and sulfide reoxidation with the increasing depths. Our results show that K-Edge XANES spectroscopy has unique advantages in morphological analysis of sulfur in sediments. XANES has provided an important analysis tool in the study of the geochemical cycle of sulfur in the aquatic ecosystem.

\section{Competing Interests}

The authors declared that there are no competing interests related to this paper.

\section{Acknowledgments}

This work was supported by the Chinese NSF projects (no. 41403113 and no. 41303097), the Environmental Science and Technology Project, and the Major Application of Basic Research Project of Guizhou Province ([2015]2001).

\section{References}

[1] N. Risgaard-Petersen, A. Revil, P. Meister, and L. P. Nielsen, "Sulfur, iron, and calcium cycling associated with natural electric currents running through marine sediment," Geochimica et Cosmochimica Acta, vol. 92, pp. 1-13, 2012.

[2] G. Billon, B. Ouddane, and A. Boughriet, "Chemical speciation of sulfur compounds in surface sediments from three bays (Fresnaye, Seine and Authie) in northern France, and identification of some factors controlling their generation," Talanta, vol. 53, no. 5, pp. 971-981, 2001.

[3] G. E. Likens, C. T. Driscoll, D. C. Buso et al., "The biogeochemistry of sulfur at Hubbard Brook," Biogeochemistry, vol. 60, no. 3, pp. 235-316, 2002.

[4] J. W. Morse, F. J. Millero, J. C. Cornwell, and D. Rickard, "The chemistry of the hydrogen sulfide and iron sulfide systems in natural waters," Earth Science Reviews, vol. 24, no. 1, pp. 1-42, 1987.

[5] R. A. Berner and R. Raiswell, "Burial of organic carbon and pyrite sulfur in sediments over phanerozoic time: a new theory," Geochimica et Cosmochimica Acta, vol. 47, no. 5, pp. 855-862, 1983.

[6] G. W. Luther III, T. G. Ferdelman, J. E. Kostka, E. J. Tsamakis, and T. M. Church, "Temporal and spatial variability of reduced sulfur species $\left(\mathrm{FeS}_{2}, \mathrm{~S}_{2} \mathrm{O}_{3}^{2-}\right)$ and porewater parameters in salt marsh sediments," Biogeochemistry, vol. 14, no. 1, pp. 57-88, 1991.

[7] G. W. Luther III, "Pyrite oxidation and reduction: molecular orbital theory considerations," Geochimica et Cosmochimica Acta, vol. 51, no. 12, pp. 3193-3199, 1987.

[8] D. Rickard, "Kinetics of pyrite formation by the $\mathrm{H}_{2} \mathrm{~S}$ oxidation of iron (II) monosulfide in aqueous solutions between 25 and $125^{\circ} \mathrm{C}$ : the rate equation," Geochimica et Cosmochimica Acta, vol. 61, no. 1, pp. 115-134, 1997.
[9] L. Holmkvist, T. G. Ferdelman, and B. B. Jørgensen, "A cryptic sulfur cycle driven by iron in the methane zone of marine sediment (Aarhus Bay, Denmark)," Geochimica et Cosmochimica Acta, vol. 75, no. 12, pp. 3581-3599, 2011.

[10] J. Prietzel, A. Botzaki, N. Tyufekchieva, M. Brettholle, J. Thieme, and W. Klysubun, "Sulfur speciation in soil by S K-edge XANES spectroscopy: comparison of spectral deconvolution and linear combination fitting," Environmental Science and Technology, vol. 45, no. 7, pp. 2878-2886, 2011.

[11] J. Prietzel, J. Thieme, U. Neuhäusler, J. Susini, and I. KögelKnabner, "Speciation of sulphur in soils and soil particles by X-ray spectromicroscopy," European Journal of Soil Science, vol. 54, no. 2, pp. 423-433, 2003.

[12] F. Jalilehvand, "Sulfur: not a 'silent' element any more," Chemical Society Reviews, vol. 35, no. 12, pp. 1256-1268, 2006.

[13] E. Lombi and J. Susini, "Synchrotron-based techniques for plant and soil science: opportunities, challenges and future perspectives," Plant and Soil, vol. 320, no. 1-2, pp. 1-35, 2009.

[14] D. Solomon, J. Lehmann, and C. E. Martínez, "Sulfur Kedge XANES spectroscopy as a tool for understanding sulfur dynamics in soil organic matter," Soil Science Society of America Journal, vol. 67, no. 6, pp. 1721-1731, 2003.

[15] J. Prietzel, J. Thieme, N. Tyufekchieva, D. Paterson, I. McNulty, and I. Kögel-Knabner, "Sulfur speciation in well-aerated and wetland soils in a forested catchment assessed by sulfur S Kedge X absorption near-edge spectroscopy (XANES)," Journal of Plant Nutrition and Soil Science, vol. 172, no. 3, pp. 393-403, 2009.

[16] A. Shchukarev, V. Gälman, J. Rydberg, S. Sjöberg, and I. Renberg, "Speciation of iron and sulphur in seasonal layers of varved lake sediment: an XPS study," Surface and Interface Analysis, vol. 40, no. 3-4, pp. 354-357, 2008.

[17] B. C. Bostick, K. M. Theissen, R. B. Dunbar, and M. A. Vairavamurthy, "Record of redox status in laminated sediments from Lake Titicaca: a sulfur K-edge X-ray absorption near edge structure (XANES) study," Chemical Geology, vol. 219, no. 1-4, pp. 163-174, 2005.

[18] Z. D. Jin, Y. M. Han, and L. Chen, "Past atmospheric Pb deposition in Lake Qinghai, northeastern Tibetan Plateau," Journal of Paleolimnology, vol. 43, no. 3, pp. 551-563, 2010.

[19] A.-M. Zhou, D.-S. Wang, and H.-X. Tang, "Phosphorus fractionation and bio-availability in Taihu Lake (China) sediments," Journal of Environmental Sciences, vol. 17, no. 3, pp. 384-388, 2005.

[20] J. G. Li, R. P. Philp, P. U. Fan, and J. Allen, "Long-chain alkenones in Qinghai Lake sediments," Geochimica et Cosmochimica Acta, vol. 60, no. 2, pp. 235-241, 1996.

[21] Z. D. Jin, J. M. Yu, S. M. Wang, F. Zhang, Y. W. Shi, and C.-F. You, "Constraints on water chemistry by chemical weathering in the Lake Qinghai catchment, northeastern Tibetan Plateau (China): clues from $\mathrm{Sr}$ and its isotopic geochemistry," Hydrogeology Journal, vol. 17, no. 8, pp. 2037-2048, 2009.

[22] Q. M. Li, W. Zhang, X. X. Wang, Y. Y. Zhou, H. Yang, and G. L. Ji, "Phosphorus in interstitial water induced by redox potential in sediment of Dianchi Lake, China," Pedosphere, vol. 17, no. 6, pp. 739-746, 2007.

[23] F. C. Wu, H. R. Qing, and G. J. Wan, "Regeneration of N, P and Si Near the sediment/water interface of lakes from Southwestern China Plateau," Water Research, vol. 35, no. 5, pp. 1334-1337, 2001.

[24] B. R. Davies, M. C. Thoms, K. F. Walker, J. H. O'Keefe, and J. A. Gore, "Dryland rivers: their ecology conservation 
and management," in The Rivers Handbook: Hydrological and Ecological Principles, P. Calow and G. E. Petts, Eds., Blackwell Science, Cambridge, UK, 1996.

[25] S. Peiffer, "Geochemical and microbial processes in sediments and at the sediment- water interface of acidic mining lakes," Water, Air, and Soil Pollution, vol. 108, no. 3-4, pp. 227-229, 1998.

[26] T. Larssen, E. Lydersen, D. Tang et al., "Acid rain in China," Environmental Science and Technology, vol. 40, no. 2, pp. 418425, 2006.

[27] M. Holmer and P. Storkholm, "Sulphate reduction and sulphur cycling in lake sediments: a review," Freshwater Biology, vol. 46, no. 4, pp. 431-451, 2001.

[28] A. J. C. Sinke, A. A. Cornelese, T. E. Cappenberg, and A. J. B. Zehnder, "Seasonal variation in sulfate reduction and methanogenesis in peaty sediments of eutrophic Lake Loosdrecht, The Netherlands," Biogeochemistry, vol. 16, no. 1, pp. 43-61, 1992.

[29] M. Dornblaser, A. E. Giblin, B. Fry, and B. J. Peterson, "Effects of sulfate concentration in the overlying water on sulfate reduction and sulfur storage in lake sediments," Biogeochemistry, vol. 24, no. 3, pp. 129-144, 1994.

[30] B. B. Jorgensen and F. Bak, "Pathways and microbiology of thiosulfate transformations and sulfate reduction in a marine sediment (Kattegat, Denmark)," Applied and Environmental Microbiology, vol. 57, no. 3, pp. 847-856, 1991.

[31] S. F. Ma and J. F. Banfield, "Micron-scale $\mathrm{Fe}^{2+} / \mathrm{Fe}^{3+}$, intermediate sulfur species and $\mathrm{O}_{2}$ gradients across the biofilm-solutionsediment interface control biofilm organization," Geochimica et Cosmochimica Acta, vol. 75, no. 12, pp. 3568-3580, 2011. 

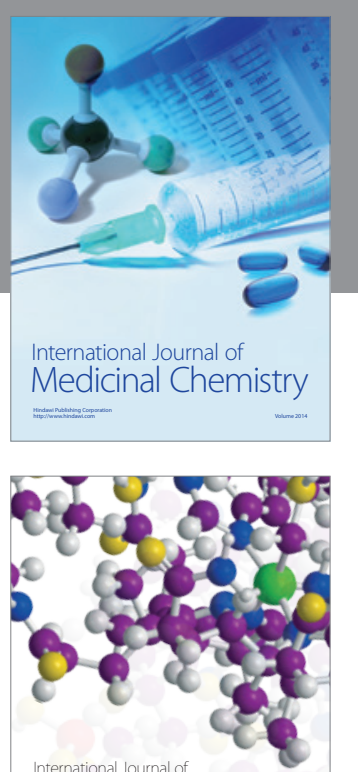

Carbohydrate Chemistry

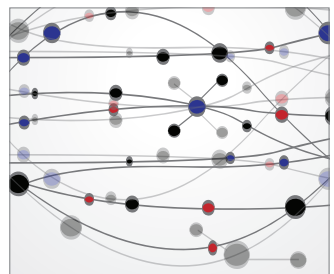

The Scientific World Journal
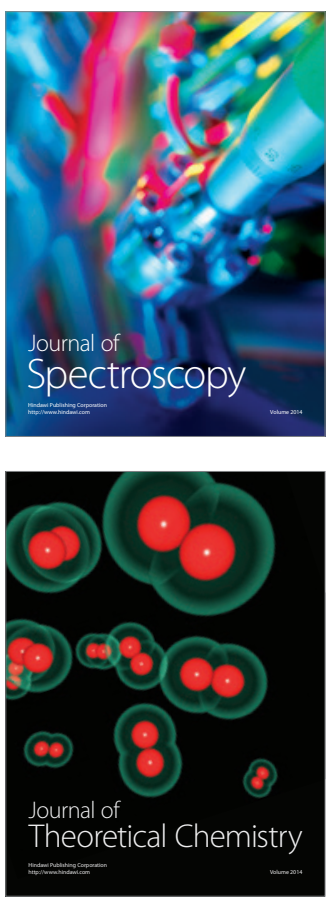
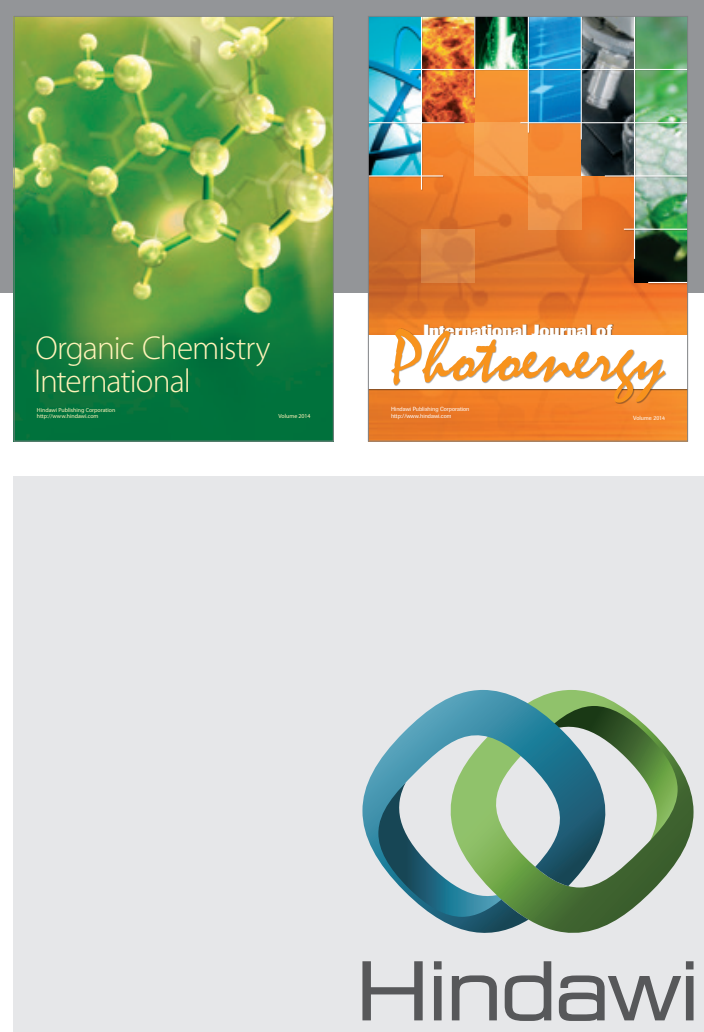

Submit your manuscripts at

http://www.hindawi.com

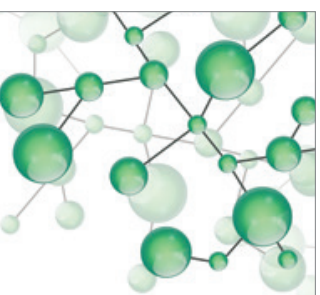

International Journal of

Inorganic Chemistry

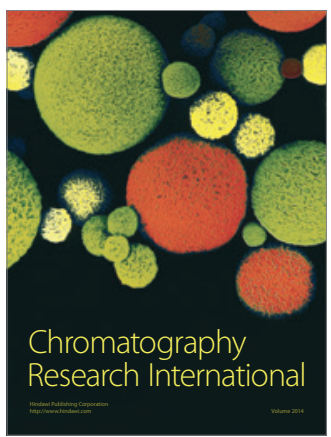

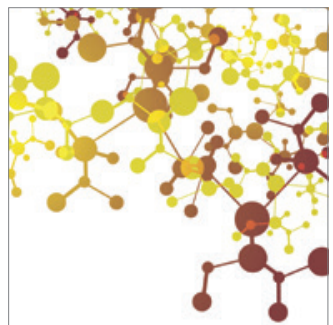

Applied Chemistry
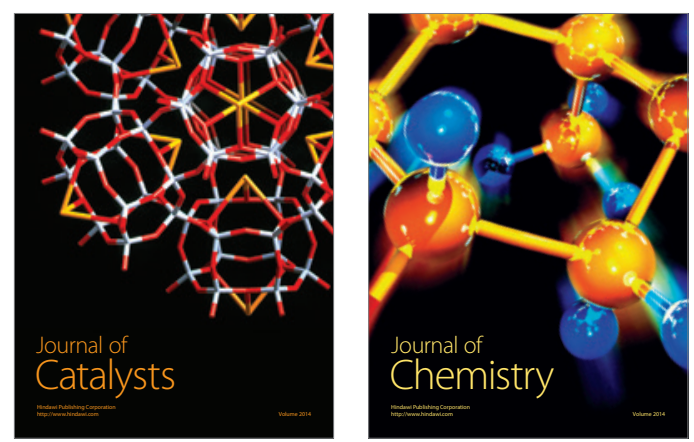
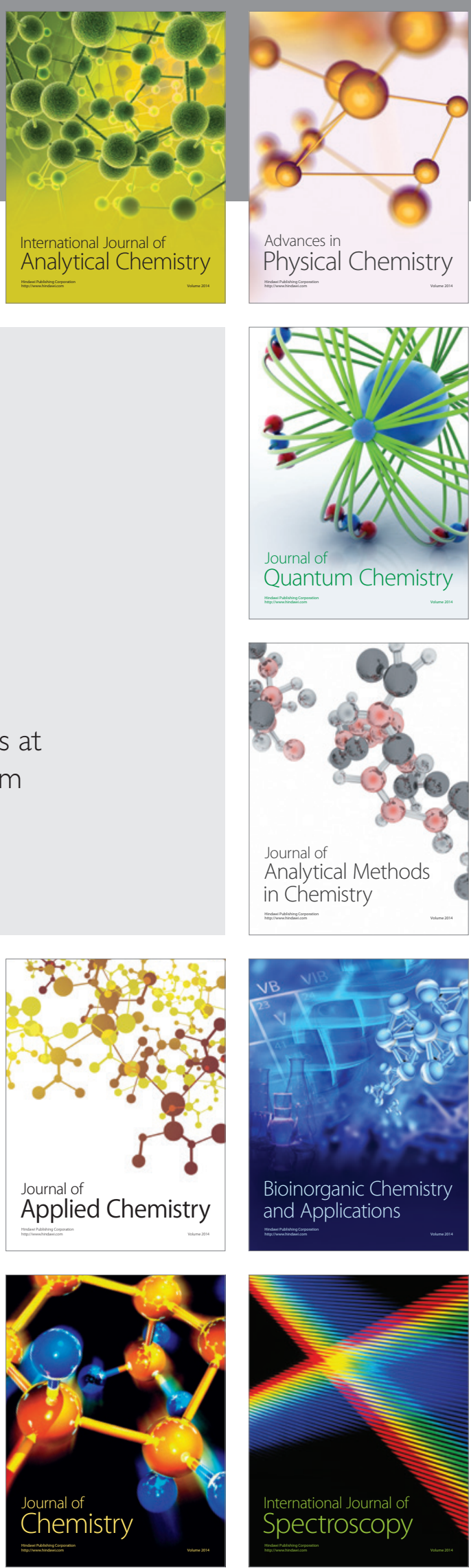